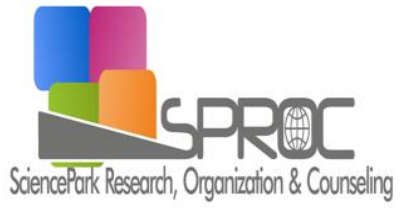

\section{Cypriot Journal of Educational Sciences}

Volume 12, Issue 3, (2017)

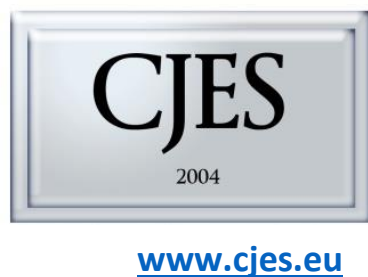

\author{
From the Editors \\ Huseyin Uzunboylu, Cigdem Hursen
}

\title{
Dear Colleagues
}

It is a great honour for us to welcome you as Editors of Cypriot Journal of Educational Sciences which has accepted publications indexed in qualified databases since 2006. Our main aim is to increase the quality of the journal day by day. We are ready to publish the new issue of Cypriot Journal of Educational Sciences which has 4 articles written by authors from Cyprus.

The aim of this issue is to give the researchers an opportunity to share their academic studies. First of all, I would like to thank all authors who have contributed to this issue. There are different focuses in the articles. For example, Gul Kahveci and Nerguz Bulut Serin discusses $4^{\text {th }}$ year pre-service school counsellors' specific knowledge related to self-confidence and skills to execute the prevention and support processes on the topic of sexual abuse in children with learning disabilities. Qualitative research data from the questionnaire answers received from 80 pre-service school counsellors were analysed using thematic analysis with an action research format. The results demonstrated that their preparation program was inadequate and needed more content relating to child sexual abuse. On the other hand, Ahmet Dogan and Ayse Bengisoy were conducted with the purpose of finding out the opinions of teachers working at special education centers about inclusive education. According to research findings, teachers working at the special education center stated that there was no special education and inclusion law in Northern Cyprus, that the law should be passed at once, that inclusive education should be regulated with this law and arbitrary practices should be ended and that uncertainties should be eliminated. They emphasized that school managers and teachers were inadequate and ignorant about inclusive education, that especially teachers were unable to prepare and implement BEP programs, and that both teachers and managers should be subjected to compulsory on-the-job training on inclusive education. Another study conducted by Gulsum Asıksoy and Fezile Ozdamli. They aim of this research is to determine the trends of education technology researches on Constructivist Learning Approach, which were published on database of ScienceDirect between 2010 and 2016. It also aims to guide researchers who will do studies in this field. According to the research results, computer-supported education was the most addressed subject in the articles. It was found out that the most frequently used tool was the computer and the most frequently used software was learning management systems in the studies. Finally, Emine Kosucu and Cigdem Hursen aimed to specify the effect of creative drama activities on candidate teachers' self-directed skills. The results obtained from the research showed that creative drama activities are effective on candidate teachers' self-directed skills. In this respect, it can be assumed that creative drama activities improved candidate teachers' self-directed learning skills. It has also been noted that the participant candidate teachers were satisfied with the applications in which creative drama activities were carried out.

I would like to express my thanks to all authors preferring Cypriot Journal of Educational Sciences to publish their articles, and also all reviewers working seriously in this process.

Best regards,

Editor-in-Chief

Prof. Dr. Huseyin Uzunboylu

Executive Editor

Assoc. Prof. Dr. Cigdem Hursen 